\title{
Citizens and Citizenship
}

\section{The Rhetoric of Dutch Immigrant Integration Policy in 2011}

\section{Dana Rem and Des Gasper}

Pre-final version of paper published in International J. of Social Quality, 8(1), 21-48; 2018.

\begin{abstract}
The past generation has seen a switch to restrictive policies and language in the governance of migrants living in the Netherlands. Beginning in 2010, a new government with right-wing populist backing went further, declaring the centrality of proposed characteristic historic Dutch values. In this article, we investigate a key policy document to characterize and understand this policy change. Discourse analysis as an exploration of language choices, including use of ideas from rhetoric, helps us apply and test ideas from governmentality studies of migration and from discourse studies as social theorizing. We trace the chosen problem formulation; the delineation, naming, and predication of population categories; the understanding of citizenship, community, and integration; and the overall rhetoric, including chosen metaphors and nuancing of emphases, that links the elements into a meaning-rich world picture. A "neoliberal communitarian" conception of citizenship has emerged that could unfortunately subject many immigrants to marginalization and exclusion.
\end{abstract}

Keywords: citizenship, communitarianism, immigrant integration, national identity, neoliberalism, population categories formation, social exclusion

In some European countries, including the Netherlands, policies that are more restrictive in regard to citizenship have been articulated since the late 1990s, partly because of the influence of right-wing populist parties. According to Friso van Houdt, the governance of migrants in the Netherlands can be considered a "strategic case" in the sense used by Robert Merton - an extreme and revealing example, for it has been marked by an early and striking switch to "radically harsh policies and public debates vis-à-vis migrants" (2014: 163), and it occurred in a country that previously had the opposite reputation, namely of a relaxed and undemanding stance toward immigrants. Governments in the Netherlands have progressively distanced themselves from multiculturalism and taken many steps to control immigration and regulate integration. New rules have entered for filtering against unwanted "Others": non-Western allochtonen (literally, people from a different soil), ${ }^{1}$ including migrants from Eastern Europe. Many of these 
people are deemed to not possess the cultural knowledge or language competencies to deserve full citizenship rights; they are seen, at best, as "citizens with an integration deficit," "discitizens" (culturally disabled for full civic participation), or qualifying for "citizenship minus". 2

Van Houdt analyzed policies up to 2008. In 2010, a new government from the Right went further to defend and extend this trend by declaring the centrality of characteristic historic values of Dutch society and (yet) further rejecting the model of multicultural society. We investigate the government's key policy document on immigrants' integration, Integratie, binding, burgerschap (Integration, connection, citizenship) (Rijksoverheid 2011). ${ }^{3}$ The policy paper (conventionally called a "policy note") presented the stance of a new coalition government of the conservative liberal People's Party for Freedom and Democracy (VVD) and the center-right Christian Democratic Appeal (CDA). This was a minority coalition that relied on support from the rightwing populist Party for Freedom (PVV) based on a formal coalition agreement; the PVV leader was a de facto member of the government. The CDA almost split in 2010 over entering this coalition, given the positions taken for many years by the PVV and its creator and leader, Geert Wilders - notably his outspoken anti-immigrant and anti-Muslim stances. When the coalition was formed and the policy note prepared, Wilders was on trial, charged with insulting and fomenting hate against Muslims, especially Moroccans, and non-Western immigrants more generally.

The Ministry of the Interior and Kingdom Relations, led in 2011 by a Christian Democrat, had prime responsibility for the policy paper, but the senior party in the coalition (the VVD) and the PVV, for whom immigration and integration issues are central, were also closely involved. Soon after this policy note was presented to the Parliament of the Netherlands, Wilders was acquitted of the charges as criminal offences. However, the VVD-CDA cooperation with the PVV collapsed after 18 months, in April 2012. This reduced the coalition to caretaker status until it was replaced after a general election by a different VVD-led coalition in November 2012. While some nuances of policy changed in the later coalition, main lines of the policy note were retained and converted into a policy implementation note in 2013 (Rijksoverheid 2013).

Using tools from discourse analysis, including analysis of the problem formulation, concepts, categories, and other aspects of rhetoric, we explore this key document. "Rhetoric" refers here to the practices of attempted persuasion of a public, in particular "the practice of civic communication" (Kock and Villadsen 2017: 572-573), and to their study. The practices include each aspect that we will highlight, such as the categorization and description of social groups, and they seek to convey not only specific arguments but also a way of viewing, feeling about, and judging a situation, including the granting of implied roles to different actors and a role of accepted authority to the author. Our rhetorical analysis is conducted not with a literary emphasis but rather for purposes of interpretive policy analysis (Gottweis 2007; Yanow 2000). Our particular questions include the following: Who are the subjects of the immigration policy, and how are they described? How are identities, purported communities, and the concept of citizenship constructed? What structures of argumentation are constructed around these concepts 
and categories? How does the text appeal to feelings and emotions and with what effects? What is the voice of authority implied in the text? (These latter three sentences reflect the classic dimensions in analysis of rhetoric: logos, pathos, ethos.)

The questions derive in part from the perspective of governmentality studies, including a hypothesis that "neoliberal communitarianism" (a concept explained in the next section) is the form of governing that now characterizes Dutch society (Schinkel and van Houdt 2010). We look in particular at problematization of some migrants and at how power shapes migrants' given identities, allocates positions in society, and can render migrants subject to marginalization, stigmatization, and exclusion. Tools from discourse analysis considered as text analysis can help one to test and discipline ideas from governmentality studies and from discourse studies considered as social theorizing (see Schrover and Schinkel 2013; Wodak et al. 2009).

\section{The Netherlands Immigration Context and Debates}

Dutch society was for a long time characterized by a tendency to institutionalize cultural pluralism in separate spheres and facilities for different cultural groups-liberals, Catholics, Protestants of various types, socialists, Jews. Some of this same thinking was applied in the twentieth century to various migrants from outside Europe, under an assumption that a secure own-cultural base was necessary to facilitate their participation in the total Dutch society.

A turn away from the idea of multiculturalism, to assimilationism, in Dutch public debate and government policy has occurred during the past generation. ${ }^{4}$ External migrants have been subjects of political problematization and dispute since the late 1980s, and a major reorientation in terms of incentives, support, and facilities occurred during the 1990s. The leaders of the government coalition in 1991 had already made explicit statements, after Frits Bolkenstein, the leader of the VVD, then in opposition, "triggered a public debate on the presumed incompatibility of Islam and 'Western values' and on the (non-)integration of Muslim migrants" (Entzinger 2006: 126). Since 1994, policy in the Netherlands has stressed good citizenship and self-responsibility. Analysts have noted, first, a shift from a focus on communities to a focus on individuals in disadvantaged positions; second, a focus on socioeconomic incorporation through labor market and education measures; and third, an increased emphasis on the cultural dimension of integration and less reliance on migrant organizations (Bruquetas Callejo et al. 2007).

From 1994 to 2002, a new government coalition excluded the long dominant (and, until then, centrist) CDA. It was led by the Labour Party (PvdA) and included the VVD and the centrist secular Democrats (D66). It took significant steps away from minority-support policies and toward an integration policy. The Christian Democrats had been known as champions of support to minorities (Entzinger 2006), but they now fell outside the government coalition for the first time since 1918. During the new government's term, migrants became problematized as socially isolated, left behind, and deficient in integration to Dutch society. The principles that had governed the earlier era of social "pillarization" ("living apart together," "preserving own 
sovereignty in one's own social space") were no longer accepted as beneficial for society as a whole. The policy focus shifted from respecting cultural diversity to promoting immigrants' participation in the wider society and economic activation. Teaching a mother tongue, other than Dutch, was removed from the school curriculum. Mandatory Dutch language and citizenship courses were initiated for all those from lower-income countries who applied for a residence permit. The integration course became national policy in 1998 under the Wet Inburgering Nederland (Dutch Integration Act).

After the major shift in integration policies in the 1990s, a second major step occurred from 2003 to 2007 under Rita Verdonk in the new post of Minister for Integration, Immigration, and Asylum Affairs. In 2007, for example, the Civic Integration Act came into force. All prospective permanent migrants from lower-income countries became required to take the language test and the social orientation test in their country of origin, and to pass it as a condition for permission to enter and reside in the Netherlands (Fleras 2009). Han Entzinger (2014) provides one analysis of this history, arguing that the policy shifts have been caused not by responses to new data but rather by a growing popular anxiety over a changing society. Similarly, there is an ongoing dispute over the actual state of integration; the findings that use standard measurements show rapid and extensive integration of most migrants, but are not accepted by many leading politicians, media commentators, and much of the general public. Sociocultural integration was widely perceived to have lagged behind, and such lags, and all problems experienced by migrants, are commonly blamed on multiculturalist policy and on migrants themselves (Duyvendak 2017).

There is no consensus among scholars regarding periodization or the varieties and appropriate naming and characterization of the different policy stances. Peter Scholten (2011) suggests further that the conventional labels should be seen as ideal types. There has always been plurality and mixture; policy framing and practice are not confined to the use of just a single current model. We thus need not a rigid historical-institutionalist analysis but rather a more nuanced constructivist analysis.

Van Houdt's (2014) study of "Governing Citizens" in the Netherlands provides a relatively flexible and sophisticated historical-institutionalist analysis using the notion of "neoliberal communitarianism." It describes the marriage that has emerged between a neoliberal stress on individual responsibility to be fit to survive in a world of flexibilized markets, and a communitarian stress on membership in local and national "community." The good citizen is good in terms of both these dimensions. This notion arose in earlier work by Willem Schinkel and Friso van Houdt (2010). Neoliberal communitarianism "differentiates . . . between good and faulty citizens [, leading to] a threefold differentiation between: (1) the active citizen; (2) the low risk citizen; (3) the high risk citizen. The latter category consists of those to whom neither facilitative nor repressive responsibilisation is [sufficient] (van Houdt 2014: 162). Van Houdt applies the notion within a framework of governmentality theory to examine the evolution of the roles of the state in recent decades in the Netherlands, with attention to policies on citizenship, 
crime, migration, and their intersections. He did not use detailed discourse analysis, nor does his study extend beyond 2008-2009. This article applies and tests some of his themes by looking in detail at the text of the crucial policy paper on citizenship and integration that emerged during the controversial coalition government of right-wing parties from 2010 to 2012.

\section{The 2011 Policy Note: Integratie, binding, burgerschap}

The policy note is a substantial document of around 9,700 words presented in six sections. The title of section 1, "A New Perspective," makes a claim to provide a new start. The section opens with a rejection of "the multicultural society" of pillarized separate communities $[1.1,1.2] .{ }^{5} \mathrm{It}$ then switches to a different objection: although many immigrants have established themselves successfully, some others have failed to build an independent life and are prone to unemployment, debt, and crime [1.2]. Subsequently, the section returns to the concern around lack of integration, and reports that "many Dutch people" feel threatened by immigration and think there are too many immigrants. It acknowledges that steps had been taken earlier to promote integration - notably, as we saw, compulsory language study and other inburgering (cultural integration to the Dutch mainstream) — but holds that more are needed [1.3]. It promises to restrict entry of people who would have weak prospects in the Netherlands; to enforce on other immigrants expectations for integration and employment; to promote respect for Dutch norms of liberty, equality, tolerance, and solidarity; and to foster acceptance of the bases for solidarity, seen as shared rules, social commitment, responsibility, and self-reliance [1.4]. It notes that these expectations for immigrants are part of a restatement and reformulation of expectations for all Dutch citizens: to take (greater) responsibility for themselves and their social environment [1.5].

Section 2, "An Obdurate Reality," opens with a review of centuries of migration affecting the Netherlands up to 2011, when 20 percent of the population, including 11 percent with nonWestern origins, "have their roots elsewhere" [2.1.2]. It is not explained that these figures include second- and even third-generation "immigrants," which is in line with the long-standing official Dutch usage of the roots-related term allochtoon (from another soil). Also highlighted are the 1 percent of the population in 2009 from Central or Eastern Europe. Subsection 2.2 on "Persistent Problems," after acknowledging progress in integration, proceeds to emphasize "still many problems and darksides," including "a very diverse population with behaviors and opinions that sometimes strongly collide" [2.2.1]. Highlighted are the overrepresentation of young second-generation "immigrants" (born in the Netherlands but having at least one immigrant parent) in criminal behavior or "suspicion of a crime" - though there is no comment on whether the police are fair in directing suspicion [2.2.2]; low levels of successful schooling and of employment, especially among refugee groups, notably Somalis [2.2.3]; concerns over levels of mutual commitment and social cohesion [2.2.5], including especially high levels of dissatisfaction regarding immigration among lower- and intermediate-educated native Dutch 
[2.2.6]; and widespread doubts over the compatibility of the cultures "of the Western and Islamic worlds", as well as fears over granting priority to values of cultural identity above core Dutch values [2.2.7]. Subsection 2.3 on "Progressive Integration" acknowledges advances among second-generation immigrants in educational accomplishment and Dutch-language use and mastery. While noting the strong ability among the second generation, much more than the first, to combine affiliations to their ancestral home and to their home in the Netherlands, and despite having recognized that "integration is a long-term process" [2.3.1], the subsection concludes that the situation is disturbing: "Half of younger Turkish and Moroccan Dutch apparently do not feel themselves mainly or completely Dutch" [2.3.3].

Section 3, "Safe, Stable, and Involved: Dutch Society as Basis for Integration and Citizenship," makes a core declaration. While Dutch society evolves, including through influences from migrants, it is not interchangeable with any other society. Its historically established fundamental features - its core values, language, and unwritten mores - are not negotiable [3.1]. Those who settle in the Netherlands must adapt to this society [3.2]. The government repeats its awareness of widespread doubts in the Netherlands about the compatibility of Islam and core Dutch values, and affirms its commitment to freedom of religion, but underlines that fundamental Dutch principles, including of democracy and rule-of-law, have priority [3.4]. Immigrants are required not only to acquire the Dutch language and the capacities to earn a living, but also to share and respect the core Dutch values, to socially integrate (though they are not required to assimilate), and to commit to the community in which they now live and to its future [3.5], in order to maintain a stable society where all feel at home [3.6]: "A more obligatory integration is necessary, because otherwise the society gradually drifts apart and nobody feels at home anymore." Further, the same duties apply to every citizen, including for involvements beyond only one's own social circle [3.6, 3.7]. In an era of growing diversity and individualism, this implies a major challenge. The task is one for all citizens, but the government will provide general support, though not subsidies for specific groups because "it is not government duty to integrate migrants" [3.6]

Section 4, "Integration Policy," specifies practical steps. Immigration policy (vreemdelingenbeleid) will be adjusted: those with insufficient prospects of self-reliant and participatory involvement in Dutch society will not be granted entry [4.0.1]. ${ }^{6}$ The required knowledge of Dutch language and mores will be demanded from existing residents, not only new entrants [4.0.2]. There will be no special policies for particular groups [4.0.3]. Expectations and treatment will be the same for all; the general policies regarding labor markets, education, housing, and other areas of relevance for all groups will provide the appropriate environment [4.0.4].

Subsection 4.1, "Qualifications and Self-Reliance," stresses people's own responsibility to invest in skills that they require for self-reliance and participation. These begin with Dutch language, literacy, and local knowledge, and extend to a lifelong duty to continue learning [4.1.1]. Social security provisions for migrants will be reduced and will be conditional on their 
own investment in mastering Dutch [4.1.2] and on their maintaining behavior (including forms of dress) that does not reduce their chances of employment [4.1.2:1]. Paragraph 4.1.3 says that people unable to pay for language education and inburgering may receive support; mainly, though, it repeats at length the obligations to acquire this knowledge and to participate in the society with respect for its "shared language, values, and beliefs." Public funding for such activities, other than via loans, would be phased out by the end of 2013 [4.1.4: 5-6]. The level of the existing inburgering examination will be raised, as will the requirements for a permanent residence permit. Failure to pass the inburgering exam will lead to the loss of a temporary residence permit — subject to consistency with international law [4.1.4]. Assessment of foreign diplomas will be accelerated.

Special concern is expressed about migrants who enter as spouses or to join their family but are not ready to participate in Dutch society. Many of them, especially young women, acquire a highly dependent position and are subject to intrafamily abuse [4.1.5]. Conditions for their entry will become tougher - including for Dutch-language skills, cultural knowledge, and financial cover - for the women's own sake and, implicitly, for the sake of Dutch society in general. Compulsory reporting of "honor"-related violence and genital mutilation will be introduced; measures against forced marriage will be strengthened $[4.1 .5: 1,4,5]$.

The policy note mentions two special categories. First, while intra-EU migrants have a right of entry to the Netherlands, those from Central and Eastern Europe often generate the same concerns as lower-skilled non-EU immigrant groups; they speak little or no Dutch, yet often become long-term or permanent residents. The note calls for functionally comparable actions in regard to these groups, too, and for an EU-wide approach given the EU provision for free movement [4.1.6]. Second, some first-generation migrants have no hope of establishing an independent life in the Netherlands and qualify for exit support via the Remigration Act; this support will be refocused entirely on them. Dual nationality will be prevented where possible [4.1.6:4].

Subsection 4.2, "Integration via General Policies," indicates general policy provisions for all Dutch residents in order to promote an integrated society. Subsidies for integration of specific groups, as well as subsidies to general-purpose minority associations and to organizations that undermine integration, are terminated [4.2.5: 6-7]. Commitment is underlined to work-relevant schooling and reduction of school dropout rates. Good practice lessons will be shared and circulated, as on how to integrate immigrant youth, while leaving local agencies to make their own choices [4.2.4, 4.2.5]. The discussion remains correspondingly rather general; all agents are called upon to play their part and meet their responsibilities. ${ }^{7}$

Section 5 places migrant integration policy in a broader perspective of "Participation and citizenship." Globalization, including intensified economic competition, will bring social strains; the need for societal cohesion and citizen contributions will grow [5.1.1]. Diversity within Dutch society must be recognized and respected but requires management through common acceptance of responsibilities for oneself and the wider society. The specification of these responsibilities is 
augmented to include active participation not only in labor markets (for oneself) and education (for one's children) but also in one's locality and social milieu. A feeling of identification with, responsibility for, and belonging to Dutch society is essential [5.2.2].

Once more the acceptance of values of equality, solidarity, mutual respect, and recognition of community is stressed. Legal requirements cannot substitute for these, but the government will provide legislative and policy support [5.2.3]. The more globalized and diverse that a country is [5.2.4], the more such interventions become required, notably those against discrimination [5.2.5]. Face-concealing clothing will be legally forbidden [5.2.5], for it undermines mutual engagement and trust. Citizen responsibility and involvement will be promoted, reversing the long-standing trend to pass responsibilities to government and professional agencies [5.3.1]. Despite the ever-greater scale of service organizations, innovative new forms for local involvement will be sought [5.3.2], such as locality budgets allocated by residents [5.3.4: 3-4]. Government and professionals will support but not displace such involvement [5.3.3].

The policy paper's short concluding section states a vision of a society that is united not by common place of origin but rather by commitment to "the historical-cultural basis of the Netherlands and the core values of its law-based society [rechtsstaat]" [6.1] and to a shared future on that basis.

Despite its opening claim to constitute a new perspective, nearly all the principles and practices enunciated in the policy note were foreshadowed in various policy documents of the previous two decades (see, e.g., van Houdt 2014: 165-171). Summarizing policy steps from the late 1980s through 2007, van Houdt found, "on the one hand, individualization, responsibilization and the introduction of a market order typical of neoliberalism, and, on the other hand, an emphasis on assimilation, moralization and a sacralization of the community typical of communitarianism." (2014: 173). The Outline Civic Integration Act of 2004, for example, already "merges a neoliberal approach based on individual responsibility, market metaphors and market behaviour with a conformist communitarian approach that is based on homogeneity, nationalist communality and the duty to conform to the specific and dominant Dutch cultural values" (2014: 173).

What, then, was new in the 2011 policy note/paper, if anything? Any new government tries to gain credit by announcing that it is taking fundamentally new steps. We suggest that something significantly new did indeed appear: elements that here moved from the worlds of media statements and some political speeches into a government policy document. Besides the language of citizenship and commitment to a shared national community, one finds (1) a classification and characterization of potential and actual citizens that is arguably in conflict with the declared principles of equal respect, including recurrent implied criticisms of Islam (we will discuss this categorization and characterization later); (2) a partly tacit, partly explicit conceptualization of citizenship that now more strongly than before includes involvement in a shared Dutch community that is conceived of as being marked by distinctive historically 
inherited Dutch values; and (3) a conception of community, connectedness, and integration that is (tacitly) in tension with contemporary global systems and cultural individualism (these features are touched on especially in the penultimate section of this article). One could also ask what the document omits, such as, perhaps, the topics of discrimination and socioeconomic marginalization. However, not all important aspects can be addressed in this article. In the next section we will try to clarify how the policy note problematizes the situation.

\section{The Problem Formulation in the Policy Note}

The 2011 policy paper provides the government's conception of Dutch society. It expresses "awareness" of many declared problems. ${ }^{8}$ Through "acknowledgment," it goes a step further in problematization, beyond those perceptions; this step involves prioritization and persistent attention, analysis, and/or endorsement of some aspects and interpretations. When a problem is "acknowledged," it is deemed serious, deserving response. ${ }^{9}$

\section{A Government That Shares Popular Dissatisfaction and Expressed Concerns}

The portrait of the situation related to migration as "problem" and the construction of "others" as problematic, as threat, are done via reference to "feelings" [1.1], felt insecurity, and "concerns of citizens" [e.g., 1.3] — highlighted by the government and taken as objective or otherwise necessitating response. The policy is presented as "developed in interaction with changed social and political perceptions of and with attention to the concerns and needs of citizens" [1.3]. As we saw, political perceptions had already shifted after 2001-2002, epitomized by the presence as Minister for Integration, Immigration, and Asylum Affairs from 2003 to 2007 of Wilders's forerunner, Rita Verdonk. Regarding social perceptions, the concerned citizens are described as those numerous Dutch who "experience the ethnic and cultural diversity . . . as a threatening experience. ... Already for almost twenty years about half of the Dutch find that too many people of other nationalities are living in the Netherlands" [1.2]. The care of the government for its own core citizens - its concerned citizens - is seen to justify tough measures.

The policy note uses a discourse of polarization: the world of "own citizens" (eigen burgers), to whom the government has a duty [3.6], and the world of "others," presented as a threat, a burden, "an obdurate reality" (section 2 title). An insider world and an outsider world are constructed: those who must be protected (nominated as "citizens" or "own citizens") and those who generate the threats, who must be treated firmly (for example, those who by their dress code or their insufficient language knowledge jeopardize their chance to participate in the mainstream society), generically nominated as people who have their roots elsewhere.

The concerns - the feelings of insecurity in relation to threats - are typically expressed as follows: first, in impersonal terms, without a specified holder of the feelings, and referring to an abstract reality (e.g., the opening sentence, "Integration is a subject addressed with mixed 
feelings nowadays" [1.1]); second, as being shared by the government (e.g., "The government shares this dissatisfaction" [1.2]); leading to, third, the government becoming the representative for the feelings of its citizens, its "own citizens," above the others.

The Identified and Formulated Problems: Multiculturalism, Lagging Integration, Dependence

A starting point in the government's problematization is multiculturalism, presented as a model that "has failed" [1.1] to give "a solution for the dilemma of the plural society" [1.2]. The government shares "this dissatisfaction over the multicultural society" [1.2] and "emphatically takes distance from the relativism . . . in the concept of multicultural society" [3.1]. The object of problematization here is an abstract one. The policy note rejects a conceptual model, which is considered guilty of not offering a "solution" [1.2] to real problems.

In the further problem formulation, regarding assumed "persistent [ongoing] problems" [2.3.1] in the field of integration, two narratives compete. In one narrative, integration "is truly visible and many migrants found their way successfully" [1.2], while the other generates government concern and demands policy intervention: "Too many children grow up in dysfunctional families in an environment where unemployment, debts, school failure, and criminal behavior are the order of the day," leading to "a growing concern that the integration in the social-cultural field is lagging behind and that differences become persistent and harden" [1.2]. This latter narrative dominates, and creates a state of concern regarding "those migrants who fail to build an independent existence in the Netherlands" [1.2]. An emphasis on the deviant, dysfunctional, indebted, and/or criminal migrant easily becomes read as presenting typical attributes of immigrants. Overgeneralizations and caricatures feed beliefs that the problems are never-ending and serve to justify fears and rejectionism toward migrants, which the government then takes up and expresses on behalf of its "own citizens" [3.6], as in the following: "Many Dutch experience ethnic and cultural diversity . . . as a threat and not as an enrichment" [1.2].

According to the policy note, "the government is aware of the negative effects of immigration and lagging-behind integration, and it combats this with a range of measures and acts against norm-breaking behavior. However, integration is more than just applying the Aliens Act and the Criminal Code" [1.4]; hence, the next paragraph speaks of "a compulsory integration." The construction of "the others" as potential "norm breakers" and the reference to the Criminal Code when thinking of appropriate interventions lead one to a picture of the migrant as a potential deviant. Problematization of the sociocultural distance between migrants and the Dutch is a core theme in the government discourse; furthermore, the distance is implicitly attributed to the migrant population and to an influx of disadvantaged migrants, rather than partly to discrimination. ${ }^{10}$ The sociocultural gap in integration is a prioritized formulated problem. It must be combated and eradicated with "a range of forceful measures" [1.4]. 


\section{The Perceived Problem of Islam, and the (Re)construction of a Notion of Society}

According to the policy note:

The government is aware of the fact that Islam, as a faith of many immigrants, in a short time became one of the largest religions in the Netherlands and it has raised concerns in some parts of the population. . . In their perceptions, the achievements of a democratic constitutional state could come under threat. . . The government acknowledges the existence of these concerns and assumes the task of taking them away where possible as they pose a threat to social cohesion. [3.4]

We read here of a society coming "under threat," a society in need of defending its internal cohesion. The discourse distinguishes communities: "the Muslim community" [3.4], an externally originated component of the society, is treated as unitary, and felt as a source of threat by and to the internal Dutch society, a constitutionally based one with seriously enforced rules and norms that are now endangered. "Social cohesion" and traditional values constitute the norms and thematic umbrella in defense of which the securitization takes place and rules are made.

\section{(Overwhelming $)$ Migration $+($ Lagging $)$ Integration $=$ Need for Citizenship}

Migration has happened "for centuries" [2.1] and has had impacts on a large scale for European societies. In regard to current immigration to the Netherlands, emphasis is placed on an "influx of disadvantaged people" [1.4], who have "roots somewhere else" [2.1.2] and some of whom were "uprooted" by war [2.1.1], and so on. Movement is presented in metaphorical terms as a result of dissolution and dislocation. This creates an expectation of a disruptive reality and difficulties in integration. Immigration is shown as an "ongoing" process [2.1 title] that causes “ongoing problems" [2.2 title]. The portrait of immigration as an overwhelming reality, whose subjects are liable to be damaged, uprooted, and potentially damaging for the host country population, provides ground for claiming that immigration reduction and intensified control are justified.

We conclude this section by returning to the theme stated at the beginning of the policy paper: a government that acknowledges popular dissatisfaction and and shares the expressed concerns. Despite the evidence it itself cites - that there is "steady integration" (2.2 title), that second-generation immigrants do far better than the first on most important indicators, and that past experience shows that integration is a process that certainly requires more than two generations - the policy paper chooses to stress that the glass is less than full and to in effect articulate fears that past immigration experience may not provide a reliable guide, especially in relation to Muslim immigrants: "The positive developments and successes, however, do not 
exclude the fact that there are still many problems and drawbacks. The settlement of some lowskilled migrants from different parts of the world has resulted in an extremely diverse population with behaviors and attitudes that sometimes clash" [2.2.1]. In the following two sections, we will examine these fears at work, first in the way in which the policy paper categorizes and describes migrant groups and then in how it defines the necessary elements of specifically Dutch citizenship and of integration specifically to the Netherlands.

\section{The Discursive Construction of Actors: Categories, Nomination, Predication}

In considering the population categorization used in the policy paper, the implicit criteria of grouping, and the ways in which the stipulated groups are labeled ("nomination") and described ("predication") (Reisigl and Wodak 2009), we are influenced by Dvora Yanow's work on population categorization (Yanow 2003; Yanow and van der Haar 2011; Yanow et al. 2016), which suggests and illustrates how "public policies are collective narratives comprising collective knowledge and identities as they link a memory of the past to the present and possibly to some future as well" (2003: 7). Yanow highlights the following elements, among others:

- A defining point of view. . . As "social" constructions, categories express the shared meaning of a group of people about what characteristics of a situation are most salient. ... The logic according to which the category set is constructed and named reflects this shared meaning from the point of view of the group creating the categories, naming them, and classifying elements within them.

- Tacit knowledge... . The cognitive organizing principles underlying category making are typically not made explicit, although this knowledge is known, usually tacitly, to members of the group. . .creating and using the categories. . . This tacit knowledge, while self-evident to group members, is often bizarre or incomprehensible to nonmembers. ... .

- Marking. ... Within a category, one element - the prototype or typification - may be considered the usual case, the norm, against which deviating — "marked" [inferior]— cases are [identified and] assessed. ...

- Occluded features and silences. [Category analysis considers which features are employed as the basis for category making, but also which traits are neglected, occluded.] (Yanow 2003: 14-15)

With these pointers in mind, we examine the category and subcategory formation and group characterization in Integratie, binding, burgerschap.

First, the policy paper refers to different levels, with embedded explicit and implicit meanings: individuals (given particular assigned responsibilities, expected to be socially involved and accountable), groups (explicitly labeled in the text, often with some negative 
connotations, e.g., as known for criminality), and organizations. The policy paper also explains the destination for integration: society, with explicit meanings of Dutch society, "our society" (a phrase used nine times), and the Dutch constitutional state. The minority groupings are seen as often locking people inside, isolating them from society.

Next, one can distinguish within the text (a) agents, meaning those actors in charge of and designated to make the policy work on others (here nominated as government, cabinet, local councils and municipalities, and various organizations), and (b) subjects of the policy design and its intended impacts. At the level of subjects, various supposed "communities" and "identities" are specified, organized sometimes in binaries (i.e., explicitly formulated in contrasting terms) but sometimes as fuzzy categories with implicit meanings, that cumulate diverse attributes belonging to more than one nominated class. The portrait of the "immigrant" is constructed by contrast with a portrait of the ideal (Dutch) "citizen," the prototype: socially involved, responsible, self-standing, committed to Dutch norms and values, and, more than that, committed to being Dutch. See Table 1 for this comparison.

Table 1. Migrant Groupings and How They Are Described and Contrasted

\begin{tabular}{|c|c|c|c|c|}
\hline Criteria & $\begin{array}{l}\text { "Marked } \\
\text { case," } \\
\text { nominated } \\
\text { as }\end{array}$ & $\begin{array}{l}\text { Connotations and } \\
\text { attributions, in contrast to } \\
\text { the prototype }\end{array}$ & Prototype & $\begin{array}{l}\text { Is the prototype } \\
\text { mentioned in } \\
\text { the policy note } \\
\text { text? }\end{array}$ \\
\hline \multirow[t]{3}{*}{ Origins } & Allochtonen & Negative & Autochtonen & $\begin{array}{l}\text { Yes, but often } \\
\text { substitute } \\
\text { wordings are used } \\
\text { (e.g., "Dutch," } \\
\text { "own citizens"). }\end{array}$ \\
\hline & $\begin{array}{l}\text { Subdivision: } \\
\text { non-Western } \\
\text { allochtonen }\end{array}$ & $\begin{array}{l}\text { Negative-generally referred to } \\
\text { simply as niet-westerse }\end{array}$ & $\begin{array}{l}\text { Western } \\
\text { allochtonen }\end{array}$ & $\begin{array}{l}\text { Non-Dutch } \\
\text { Westerners are } \\
\text { absent, } \\
\text { unmentioned. } \\
\text { Neutral meaning. }\end{array}$ \\
\hline & $\begin{array}{l}\text { Subdivisions: } \\
\text { first and } \\
\text { second } \\
\text { generations (of } \\
\text { non-Western } \\
\text { allochtonen) }\end{array}$ & $\begin{array}{l}\text { Negative compared with their } \\
\text { counterpart, autochtonen. } \\
\text { Different connotations regarding } \\
\text { failing or success stories per } \\
\text { generation. } \\
\text { Differentiated also per } \\
\text { theme/competence (e.g., language, } \\
\text { school drop-out, labor } \\
\text { participation, social benefits). }\end{array}$ & Autochtonen & $\begin{array}{l}\text { Absent as explicit } \\
\text { constructions. } \\
\text { Favorable } \\
\text { meaning, as } \\
\text { bearers of the } \\
\text { values of personal } \\
\text { independence yet } \\
\text { public spirit, etc. }\end{array}$ \\
\hline
\end{tabular}




\begin{tabular}{|c|c|c|c|c|}
\hline Religion & $\begin{array}{l}\text { Muslims } \\
\text { ("Muslim } \\
\text { community" is } \\
\text { explicitly } \\
\text { nominated) }\end{array}$ & $\begin{array}{l}\text { Negative-discussed often as } \\
\text { problem: } \\
\text { - Men: a possible threat for } \\
\text { security } \\
\text { - } \quad \text { Women: dependent } \\
\text { position/obedient/victim/expl } \\
\text { oited } \\
\text { - Youngsters: possible } \\
\text { criminals/security threat }\end{array}$ & $\begin{array}{l}\text { Non- } \\
\text { Muslims }\end{array}$ & $\begin{array}{l}\text { Absent, } \\
\text { unmarked; instead } \\
\text { appear as } \\
\text { implicitly a state } \\
\text { of freedom from } \\
\text { sacralized } \\
\text { community }\end{array}$ \\
\hline \multirow[t]{4}{*}{ Gender/Age } & $\begin{array}{l}\text { Non-Western } \\
\text { allochtoon } \\
\text { women (often } \\
\text { implicitly } \\
\text { Muslim) }\end{array}$ & $\begin{array}{l}\text { Negative: } \\
\text { - } \quad \text { Implied to be dependent / } \\
\text { often victim of domestic } \\
\text { violence and/or forced } \\
\text { marriage and hence subject of } \\
\text { legislative intervention. } \\
\text { - } \quad \text { Seen as self-excluding from } \\
\text { social participation and labor } \\
\text { market (e.g., due to covered } \\
\text { face) }\end{array}$ & $\begin{array}{l}\text { Dutch / } \\
\text { Western } \\
\text { autochtoon } \\
\text { /women }\end{array}$ & $\begin{array}{l}\text { Absent, } \\
\text { unmarked, neutral } \\
\text { meaning }\end{array}$ \\
\hline & \multirow[t]{2}{*}{$\begin{array}{l}\text { Non-Western } \\
\text { allochtoon } \\
\text { young people }\end{array}$} & $\begin{array}{l}\text { Non-Western allochtoon } \\
\text { boys/males: sometimes negatively } \\
\text { characterized by high school } \\
\text { dropout, low income, low } \\
\text { participation in the labor market; } \\
\text { crime and drug traffic (esp. } \\
\text { Somalis) }\end{array}$ & $\begin{array}{l}\text { Dutch / } \\
\text { Western } \\
\text { autochtoon } \\
\text { boys }\end{array}$ & $\begin{array}{l}\text { Absent as explicit } \\
\text { construction (but } \\
\text { implied by } \\
\text { comparison in the } \\
\text { fields of crime, } \\
\text { school dropout, } \\
\text { labor } \\
\text { participation). } \\
\text { More successful. }\end{array}$ \\
\hline & & $\begin{array}{l}\text { Non-Western allochtoon girls: } \\
\text { positively described in education } \\
\text { sector, including in some cases } \\
\text { when compared with their } \\
\text { traditional Dutch counterparts } \\
{[2.3 .1]}\end{array}$ & $\begin{array}{l}\text { Dutch / } \\
\text { Western } \\
\text { autochtoon } \\
\text { girls }\end{array}$ & $\begin{array}{l}\text { Dutch girls are } \\
\text { only briefly } \\
\text { present as a self- } \\
\text { standing } \\
\text { construction. }\end{array}$ \\
\hline & $\begin{array}{l}\text { Elderly(non- } \\
\text { Western } \\
\text { allochtoon }\end{array}$ & $\begin{array}{l}\text { Negative-dependency, low } \\
\text { social participation, little or no } \\
\text { language competency. }\end{array}$ & Dutch elderly & Absent \\
\hline
\end{tabular}

Several aspects deserve note. The phrase "the Dutch society" is used 19 times in the policy paper: "The Dutch society is the one in which those who want to settle must learn to live, and to which they must adapt themselves and conform" [3.3]. Second, henceforward in integration policy, "origins play no role, the future does" [4.3]; policy will be oriented only to 
building new (Dutch) identities. Third, we saw the dismay expressed that "half of younger Turkish and Moroccan Dutch apparently do not feel themselves mainly or completely Dutch" [2.3.3], which implies that complex identities are not acceptable. The concepts of "communities" and "identities" demand more elaborate discussion, for the terms are loosely used, including in the policy note. They involve mechanisms of self-versus-others perception and are the object of analysis later in our article.

We thus find various types of identified subjects of migration/integration policy (see Table 1). Much of the classification uses binary groups; one highlighted part of each binary often becomes a targeted category, a subject of policy. The major binary is autochtoon/allochtoon. Its use in the Netherlands dates from 1971 (Verwey-Jonker 1971), and from the Dutch Central Bureau of Statistics's standardized definition in 1999 (Yanow and van der Haar 2013). ${ }^{11}$ A single non-Netherlands-born parent suffices to place a person in the allochtoon category. It is further bisected into Western allochtoon and non-Western allochtoon, in which the latter is the problem group. ${ }^{12}$ Non-Western allochtonen are further divided into first generation and second generation. In the first-generation case, the person is born outside the Netherlands, and in the second-generation case, born in the Netherlands. ${ }^{13}$

One can extend this analysis of characteristics and categorizations used or implied in the policy paper's description of migrants. ${ }^{14}$ Regarding highlighted perceived actual or potential problem groups among the (typically non-Western) allochtoon subjects, we find indicated the following: people who (intend to) live permanently in the Netherlands but who have little chance of creating an independent life there because of low qualifications, low workforce participation, and high recorded unemployment and welfare dependence; people who diminish their chances in the labor market by their dress code; people who do not master the Dutch language at all or enough to obtain a paid job; and people who have encounters with the police. These are groups described in terms of how they are perceived as problematic by the government.

The overrepresentation of migrants and their children in recorded crime figures is formulated as a matter of high concern, the first in the list of problems: "From figures cited from the Utrecht criminologist Bovenkerk in 2009, the seriousness of the problem appears yet greater. He concludes that in Rotterdam no less than $54.7 \%$ of the boys with a Moroccan background had contact at least once with the police" [2.2.2]. This shows only the share that had "contact" with the police, but the policy paper hints at criminal elements who require continuing attention. However, its section 2 shifts rapidly between different variables, and groups and regroups people in mixed samples. This makes the reader lose clarity with regard to which individuals/groups the problem is constructed and whether there is a consistent comparator group (for each norm).

The heavy emphasis on certain cases concerning some members of a group means that the predominant collocations are [problem] + [minority group name]. ${ }^{15}$ The minority group name becomes primed to carry connotations of the negative terms with which it is so frequently paired (see also Pérez-Paredes et al. 2017). A discussion of that type occurs, for example, in section 2 of the policy note, regarding immigrants and their children as overrepresented in the lowest 
economic classes, with low labor participation and dependency on social benefits. The following groups are problematized as showing low-to-lowest labor market participation in relation to indigenous Dutch: Surinamese-Antillean-Turkish-Moroccan. Again, the groupings and comparisons seem casual and oscillate between different sorts of comparison group, times, and places.

A typical binary construction (problem causers, problem sufferers) is reproduced in the distinction between migrant men, who cause problems, and migrant women, who have problems (Roggeband and Verloo 2007); and similarly between being a risk (to security) and being at risk (of trafficking, prostitution, forced marriages, situations of domestic violence, or being victims of honor killings) (Schrover 2009). The policy note highlights especially "the group of immigrants - mostly young women - who come to the Netherlands within the framework of family reunification." This "continuing flow" causes "serious delays to the integration process" because the entrants "are insufficiently prepared for their new life in our society" and instead can "end up in a highly dependent position" and suffer "honor-related violence, polygamy, and forced marriages" [4.1.5]. New requirements will be placed on them, in addition to preentry knowledge of Dutch and "the general obligation to integrate," including that such entrants must have independent housing and health insurance.

We note one further problem group that is delineated in the document. Among migrants from the European Union, who as EU citizens are entitled to live and work in the Netherlands, "temporary migrants from Central and Eastern European countries" supposedly put a high "burden on certain old inner-city districts," are poorly integrated through a lack of knowledge of Dutch, yet can eventually settle permanently. These are new, prospective, seriously lagging groups. Tailor-made policy for such migration is required, maneuvering in relation to limits set by European law, including facilitating where appropriate "termination of residence and return to country of origin" [4.1.6].

\section{Key Concepts: Communities and Connection, Citizenship, and Integration}

\section{The Triad: Citizenship-Community-Integration}

Integratie, binding, burgerschap is built from contrasting strands. It emphasizes, first, individual rights, liberties, and self-standing and responsible citizens, and, at the same time, a society in which citizens are expected to participate, bond, and share common values of "their" society-a cohesive society of people with shared language and cultural roots. It matches Schinkel and van Houdt's description of "neoliberal communitarianism":

a policy style "that operates both in an individualizing (citizenship as individual participation and responsibility) and a de-individualizing way ("community" at various aggregate and localized levels as frame of "integration"). It thus combines a 
communitarian care of a Dutch culturally grounded national community . . . with a neoliberal emphasis on the individual's responsibility to achieve membership of that community. (2010: 696)

Some authors see a specifically Dutch historical tradition, a stress on countering dangers of falling apart, in a society divided between pillarized groups. Neoliberal communitarianism occurs more widely than in the Netherlands, but what matters for our purposes is the tight packaging in the Netherlands of notions of citizenship, integration, and national community: "minority policy became integration policy and integration became defined as citizenship and later as active/moral citizenship" (van Houdt 2014: 174).

\section{"Binding": Connectedness and Community}

Binding is a harder term to translate than integratie or burgerschap; it evokes cohesion and connectedness within a community. In Dutch integration policy, the desired connections are not only to "local" and small-group communities of various types, but fundamentally also to a national cultural "community," of a virtual type, with shared Dutch norms and values. "Dutch governmental communitarianism is a civic kind of nationalism that merges 'nation,' 'society,' 'community' and 'morality"' (van Houdt 2014: 174).

The policy paper expounds its approach to integration as "rooted in the notion that the Dutch society is not just a random collection of people who happen to live here, but rather a community of citizens with a shared language, values, and beliefs" [4.1.3]. Dutch society requires "a common foundation of shared values and norms" [3.6]. The paper's reasoning reflects and contributes to a felt tension in relation to "the Muslim community" [3.5], seen as also united by shared values and beliefs, but ones that differ from the values of the Dutch liberal constitutional state and mainstream Dutch society. "When 'community' is emphasized in recent policy documents, only one 'ethnic community' is preferred. This is 'Dutch society' that is characterized by its ... 'Dutch norms and values"' (van Houdt 2014: 174).

\section{"Burgerschap": Citizenship}

The notion of citizenship now in force in Dutch policy is more than pure liberal citizenship, the acceptance of and respect for the legal rights and duties of a citizen; it has absorbed a communitarian strand of emphasizing active participation in an ethical community of shared values (Schinkel and van Houdt 2010; van Houdt 2014). In the words of Herman van Gunsteren (2008), it is epitomized no longer by the right to be different but by the duty to be similar.

The policy paper's concept of citizenship articulates all these elements: participation "in the labor market, in education, in one's own neighbourhood and social environment, . . . by being involved with fellow citizens [etc.]," "building up an independent existence, ... being self- 
standing, ... knowing and applying the rules of the Dutch society" [5.2.1]. It adds that necessary conditions for citizenship — and not just with instrumental value —include "mastering the Dutch language" and "that the citizen considers him- or herself a citizen of the society, identifies with the society, feels responsible for it, and wants to belong to it" [5.2.2].

Actual residents can then fall into various de facto categories according to their closeness to this prototype, in a chain from the good active citizens to the bad/deviant/left-behind ones. Full citizens contribute to the society's foundations and future, understand the efforts of the preceding generations, and have knowledgeable access to collective memories. The on-trial citizens include oldcomers who had acquired the ("liberal") legal status of citizens but are now expected to show their deservingness and commitment. High-risk citizens, typically from specific groups among those of Moroccan, Turkish, Surinamese, or Antillean descent, include those identified as in or at risk of joining criminal groups. Semi-citizens are those who have entered in dependent and marginal situations, like allochtoon brides and some lower-skilled labor migrants. De facto noncitizens include those convicted for offences and subject to expulsion.

We hypothesize that the concept of citizenship is selectively applied to immigrants, in terms of constructed collective identities. The ethnic, cultural, and/or religious identities of nonWestern allochtonen are framed by the government as problematic: migrants of a specific ethniccultural-religious background may be seen as burden for the welfare state or as threats for the democracies of the West.

\section{"Integratie": Conceived as the Path to Citizenship and Cohesion}

Immigrant (non)integration has been defined as a social problem, but its meaning has remained unclear and contested. The current bias in the Netherlands becomes relatively explicit in Integratie, binding, burgerschap: "integration" means integration specifically into Dutch society as presently constituted and as defined by the dominant culture, its norms, and its values. As we saw, the phrase "the Dutch society" is used 19 times in the 15 pages of the policy paper. Maintaining the existing character of Dutch society is the central value associated with the official idea of integration. This form of integration is considered to contribute to preservation of social stability.

The policy paper itself does not convey the full power of the current integration concept as a tool giving instructions: for the strangers, the foreigners, the newcomers. It talks instead of a society "under pressure" [1.3] and in need of intervention to make people "feel at home" again [3.6]. Such interventions began in the late 1990s and have intensified over time. The 2011 policy paper is perhaps notable even more for its stronger language than for entirely new measures: "A more obligatory integration policy is necessary and justified because otherwise the society gradually drifts apart, citizens just pass each other by, and finally nobody feels at home in the Netherlands." Further, "Integration of migrants and the strengthening of solidarity and 
citizenship in the society as a whole are therefore [treated as] closely intertwined and jointly form the expression of the values of a society one would want to identify with. This presupposes a common foundation of shared values and norms" [3.6].

However, there was indication too of new policy measures, including stronger filteringout at the stage of requested immigration, with reference to integration expectations; stronger requirements, monitoring, and sanctions in regard to inburgering trajectory; retraction of social benefits for those who do not master Dutch and thereby reduce their chance of employment; and specific monitoring, discipline, and sanctions regarding Antillean and Moroccan supposed highrisk youth, through mobilizing local governmental institutions and organizations, with talk of expulsion in extreme cases.

A culturally protectionist policy frames own-citizens as in need of protection, while immigrants get duties and obligations. While support from government is reduced or eliminated, an obligation to integrate and to cover the corresponding costs is stated emphatically. By now, according to van Houdt, Dutch migration policy treats "lack of integration as a lack of will to integrate. And it thereby turns citizenship into a status that is not fully ascribed because it is [considered] not fully achieved. [Yet this] happens only in case of 'non-western allochthons"' (van2014: 175).

\section{The Rhetoric and Framing of Immigrant Integration Policy}

We have looked at several aspects of the system of attempted persuasion in Integratie, binding, burgerschap: its problem formulation, its nomination and predication of population categories, and its central concepts of citizenship, community, and integration. In this final substantive section, we synthesize ideas and add some attention to other elements of the overall rhetorical system: the chosen metaphors and the nuancing of emphasis, backgrounding certain matters and foregrounding others. These elements of rhetoric are essential for the integration and fuller meaning: they stitch the argumentative elements together into a meaning-rich overall world picture with a particular emotional content and force. Metaphor analysis in particular reveals much about the how and the why of the framing and argumentation.

Earlier we looked at the problematization of non-Western allochtonen, and then at how the reconceived - moralized, neoliberal communitarian - conception of citizenship shapes migrants' given identities and allocates and reallocates positions in society. This concept of citizenship can be seen to function as a rhetorical tool for filtering, "taming," and sometimes rejecting immigrants. Central to the reconceived notion of citizenship is a notion of distinctive traditional Dutch national identity. Citizens must absorb and commit to that notion. Integration means the corresponding process and achievement. This perspective reflects the following: strong commitment to a relatively simple notion of Dutch identity; a rather simple notion of identity in general, namely that identities must be simple; and a related tacit insecurity about the resilience (as opposed to the desirability) of this Dutch identity. ${ }^{16}$ 


\section{A Strong Commitment to a Relatively Simple Notion of Dutch Identity}

The government centrally declared that Dutch society, howsoever it may change under the influence of migrants, is distinctive and not interchangeable for any other society [3.1]. This is a declaration of conviction and commitment that Dutch society will preserve a distinctive own identity. The identity is defined through a system of references to own character, past, traditions, roots, landscape, landmarks, memories, and cultural features, all shared with and recognizable by those who have contributed to and emerged from this history. These collective memories and a common code of symbols and behavioral constants have a prior status and define the national identity and the portrait of the citizen born "from the [national] soil": the autochtoon, the full citizen, the one rooted culturally and historically in that ground, the one who embodies the collective spirit of the nation and cumulated efforts of generations [3.2].

The government declaration of confidence in and commitment to this notion of Dutch society accompanies and counterbalances the publicized ambition to make the land a home for deserving others who themselves commit to this notion. Deservingness is constructed rhetorically as a matter of personal choice. Individuals must in addition prove willingness to contribute to society and gain legal entitlements in conformity with the specified rules and societal norms. That is how those who were not born from the soil may qualify as potential or transitional citizens, citizens whose status remains a matter of ongoing potential reconsideration whenever they are deemed to not satisfy the requirements: self-reliance, contribution, participation, legal status of settlement, commitment to the shared norms and values. In contrast, for those who are deemed to belong to the national soil, their access to the history of common beliefs and shared meanings is assumed and guarantees full citizenship rights.

\section{A System of Simplistic Concepts}

The system of thinking uses a series of simplistic concepts. It adopts a communitarian notion of society as a "community of shared language, values, and beliefs" [4.1.3]. It correspondingly periodically seems to assume that integration to one societal system necessarily requires decoupling from others. In John Berry's $(1997,2011)$ terms, it thereby leans toward a demand for assimilation; indeed, given its mobilization of policy instruments and sanctions, toward forced assimilation. ${ }^{17}$ It frequently treats citizens (the burgers, who have concerns and worries) and "newcomers" as polar concepts [e.g., 1.3]. Thus it perpetuates the flawed autochtoon/allochtoon terminology and its application to the children of mixed marriages - steps that undermined integration. The language of "soil/earth" (Geschiere 2009), implicitly as reflection of "blood," fanned pressures to extend the alienating terms to third- and fourthgeneration "immigrant" Dutch citizens, including those of mixed "blood": a disastrous conceptual time bomb. ${ }^{18}$ 
Foregrounding and Backgrounding in Ways That Reflect (and Fan) Insecurity about Resilience of the Simplistic Notion of Dutch Identity

The policy note employs rhetorical constructions that downgrade positive integration steps made by immigrants and focus on negative perceptions and fears. This focus is adopted from the second paragraph on: "Although integration is undoubtedly visible and many migrants have found their way successfully in the economy, culture, politics, and education, the concern over those migrants who fail to build an independent existence in the Netherlands dominates" ${ }^{\text {" }}$ [1.2, emphasis added for the diminisher term]. Furthermore, the government then commits itself to prioritizing those concerns and fears. The government declares that it "is attentive to [or focuses on] the negative effects of immigration and lagging integration" [1.4]. Objective progress is subordinated to popular perceptions and minority cases. Again: "The ongoing debate over immigration and the criticism of the multicultural society might lead to the misconception that overall there is no integration. The reality is different. Figures and statistics show progress. Behind this overall picture, however, lies hidden a great diversity between and within groups" [2.2.1, emphasis added for the stresser term].

The subjective fears are given authority in other ways, too, including through repetition and impersonal articulation, from the start of the policy note. "Again and again it appears that many Dutch experience the ethnic and cultural diversity that characterizes the Netherlands not as an enrichment but as a threat" [1.2, emphasis added]; even though, as often noted, those fears are greatest in the areas with the fewest immigrants. Similarly: "It has been noticed that . . . unlike what was thought and expected the different ethnic and cultural groups [in European societies] . . . have not mutually come together in a new unity" [1.1]. This impersonal formulation gives no specification of who supposedly expected what, or what measures of convergence are used in assessment.

\section{Metaphors of Dangerous Flow and Securing the National House}

The policy note employs standard metaphors regarding migration as a disruptive flow and integration as a process of building and securing personal and national homes. Migration "flows" $[1.1,1.2,2.1 .1,2.1 .2,2.2 .1,2.2 .5]$ include an "influx of [the] disadvantaged" [1.4], the products of the "dissolution" of colonial empires [2.1.1], and those "uprooted" by war [2.1.1]. The flows are ongoing [2.1], are difficult to control, and create ongoing problems [2.2]. The fear is that Dutch society "gradually drifts apart" [3.6].

The document avoids the common metaphor of building bridges, for that could suggest endorsement of pluralism. Instead, it talks repeatedly of migrants' duty to "build an independent existence in the Netherlands" [1.2]; the ability to "build a home by [their] contribution to that society" [3.1, 3.6]; "building a new existence" in a new country [3.3]; choosing to "build a life in 
the Netherlands" [3.5]; the knowledge and ability "to build an [independent] life [or existence]" [4.0.2, 4.0.4, 4.1.1, 4.2.1, 5.2.1] in the Netherlands. It uses repeatedly also the language of "home" (Duyvendak 2017): a future in which "nobody feels at home in the Netherlands anymore" [3.6]; "all those who want to make our society a permanent home" [3.2]; and, again, in its conclusion section, "a Dutch society that all who settle here can make their home through their active participation."

Suggested by the recurrent emphases on building and home is a notion of the host society as a house with existing foundations that "arose through the commitment, efforts, expectations, and beliefs of preceding generations, on which foundations it will develop further through the commitment, efforts, expectations, and beliefs of all those who want to make our society a permanent home" [3.2]. The discursive construction of citizenship in the policy note suggests a prior "owner" status for autochtoon citizens. They possess the ground and the codified scheme of the house, know the foundations, know how to read the codes, and are bound to the property. The others, the on-trial entrant candidate citizens, do not know much and are at best accepted as potential contributors, under supervision and guidance. Their bond to the house can be limited to the work they deliver, and their contract is dependent on their performance: they can be hired and fired.

\section{Concluding Remarks}

We hope to have shown the usefulness of text-focused discourse analysis, including rhetoric analysis, as tools of interpretive policy analysis (Gottweis 2007; Yanow 2000), here specifically regarding issues of social integration and cohesion. Our research questions derived in part from governmentality studies, including the hypothesis that neoliberal communitarianism now characterizes governance in the Netherlands (Schinkel and van Houdt 2010). Our analysis then complements such work from governmentality studies by adding a more nuanced constructivist viewpoint. It has supported but refined the hypothesis.

Arising from this article's exploration are some questions about current policy in the Netherlands, including how far its characterization of potential and actual citizens follows principles of equal respect and how far the conceptions of community, connectedness, and integration match contemporary realities. One thus must ask whether and how the concept of citizenship that is now being used contributes to migrants' marginalization and exclusion.

Much further work is possible to extend, deepen, and test this sort of analysis. Central in this, we suggest, and going beyond policy documents, will be to examine how migrants themselves relate to the citizenship-and-integration policy and its simple concepts, in order to see how far it is productive or counterproductive. Seeking a perspective with a richer conceptual basis becomes relevant insofar as successful integration requires processes of mutual accommodation. Rinus Penninx and Blanca Garcés-Mascareñas's 2016 edited volume provides an example, looking at migrants also as agents of transformation, and exploring "integration" as 
involving multilateral processes instead of only as one-way "absorption."

$* *$

\section{Acknowledgments}

We thank our seminar audiences at the Hellenic American University in Athens, De Montfort University in Leicester, and the International Institute of Social Studies in The Hague for their comments and advice. In addition, we would like to thank Marlou Schrover, Dvora Yanow, an anonymous referee, and the journal editor for very helpful suggestions and corrections on an earlier version; Lennart and Daria Rem for encouragement and support; and B\& Vertalingen for help in translation.

Dana Rem is a social scientist with a formation in psychology, sociology, criminology, policy analysis, and discourse analysis, and degrees from the University of Bucharest and the International Institute of Social Studies in The Hague. She has experience in various sectors of social policy and justice system reform, including in international public sector projects, research and academia. Since 2014, she runs the European Research Initiative for Critical Migration Studies (ERIMIS), including work on immigrant integration policies in the Netherlands. Email: erimis2014@gmail.com

Des Gasper is a professor in public policy at the International Institute of Social Studies in The Hague, a graduate school of international development studies within Erasmus University Rotterdam in the Netherlands. He is a coeditor of recent migration-related works that include the open access volume Gender, Migration and Social Justice (Springer, 2014), Transnational Migration and Human Security (Springer, 2011), and "Trans-local Livelihoods and Connections" (special issue, Gender, Technology and Development, 2008). Email: gasper@ iss.nl

\section{References}

Berry, J. W. 1997. “Immigration, Acculturation, and Adaptation.” Applied Psychology 46 (1): 534.

Berry, J. W. 2011. "Integration and Multiculturalism: Ways towards Social Solidarity." Papers on Social Representations 20: 2.1-2.21.

Bruquetas Callejo, M. D. M., B. Garcés-Mascareñas, R. Penninx, and P. Scholten. 2007. Policymaking Related to Immigration and Integration: The Dutch Case. IMISCOE Working Paper no. 15. Amsterdam: Instituuut voor Migratie en Etnische Studies.

Duyvendak, J. W. 2017. Thuis: Het drama van een sentimentele samenleving [At Home: The drama of a sentimental society]. Amsterdam: Amsterdam University Press. 
Entzinger, H. 2006. "Changing the Rules while the Game Is On: From Multiculturalism to Assimilation in the Netherlands." In Migration, Citizenship, Ethnos: Incorporation Regimes in Germany, Western Europe and North America, Y. Michal Bodemann and Gökçe Yurdakul, 121-144. New York: Palgrave Macmillan.

Entzinger, H. 2014. "The Growing Gap between Facts and Discourse on Immigrant Integration in the Netherlands." Identities: Global Studies in Culture and Power 21 (6): 693-707.

Fleras, A. 2009. The Politics of Multiculturalism. New York: Palgrave Macmillan.

Foucault, M. 1984. "Polemics, Politics and Problematisations: An Interview with Michel Foucault.” Trans. Lydia Davis. In The Foucault Reader, ed. Paul Rabinow, 381-390. London: Penguin.

Geschiere, P. 2009. The Perils of Belonging: Autochthony, Citizenship, and Exclusion in Africa and Europe. Chicago: University of Chicago Press.

Gottweis, H. 2007. "Rhetoric in Policy Making: Between Logos, Ethos, and Pathos." In Handbook of Public Policy Analysis: Theory, Politics, and Methods, F. Fischer, G. J. Miller, and M. S. Sidney, 237-250. Boca Raton, FL: CRC Press.

Kock, C., and L. Villadsen. 2017. "Rhetorical Citizenship: Studying the Discursive Crafting and Enactment of Citizenship." Citizenship Studies 21 (5): 570-586.

Lucassen, L., and J. Lucassen, 2015. "The Strange Death of Dutch Tolerance: The Timing and Nature of the Pessimist Turn in the Dutch Migration Debate." Journal of Modern History 87 (1): 72-101.

Penninx, R., and B. Garcés-Mascareñas, eds. 2016. Integration Processes and Policies in Europe: Contexts, Levels and Actors. Dordrecht: Springer.

Pérez-Paredes, P., P. Aguado Jiménez, and P. Sánchez Hernández. 2017. “Constructing Immigrants in UK Legislation and Administration Informative Texts: A Corpus-Driven Study (2007-2011)." Discourse and Society 28 (1): 81-103.

Ramanathan, V., ed. 2013. Language Policies and (Dis)citizenship: Rights, Access, Pedagogies. Bristol: Multilingual Matters.

Reisigl, M., and R. Wodak, 2009. “The Discourse-Historical Approach.” In Methods of Critical Discourse Analysis, ed. R. Wodak, M. Meyer, 87-121. London: Sage.

Rijksoverheid. 2011. Integratie, binding, burgerschap [Integration, connection, citizenship]. Netherlands Government policy note, Ministry of Internal Affairs and Kingdom Relations, Hague. Originally at https://www.rijksoverheid.nl/documenten/beleidsnota-s/2011/06/16/integratienota; now at https://www.dreuz.info/wp-content/uploads/integratienota.pdf

Rijksoverheid. 2013. Agenda Integratie [Integration agenda]. Netherlands Government policy implementation paper. Ministry of Internal Affairs and Kingdom Relations, The Hague. . https://www.tweedekamer.nl/kamerstukken/brieven_regering/detail?id=2013Z03387\&did $=2013$ D06989

Roggeband, C., and M. Verloo. 2007. "Dutch Women Are Liberated, Migrant Women Are a 
Problem: The Evolution of Policy Frames on Gender and Migration in the Netherlands 1995-2005." Social Policy and Administration 41 (3): 271-288.

Schinkel, W., and F. van Houdt. 2010. "The Double Helix of Cultural Assimilationism and Neoliberalism: Citizenship in Contemporary Governmentality." British Journal of Sociology 61 (4): 696-715.

Scholten, P. 2011. Framing Immigrant Integration, Dutch Research-Policy Dialogues in Comparative Perspective. Amsterdam: Amsterdam University Press.

Schrover, M. 2009. "Family in Dutch Migration Policies, 1945-2005." The History of the Family 14 (2): 191-202.

Schrover, M., and W. Schinkel. 2013. "The Language of Inclusion and Exclusion in the Context of Immigration and Integration." Ethnic and Racial Studies 36 (7): 1123-1141.

van Dijk. T. 1992. "Discourse and the Denial of Racism." Discourse and Society 3 (1): 87-118. van Gunsteren, H. 2008. Bouwen op burgers: Over cultuur, preventie en de eigenzinnige burger [Building on citizens: About culture, prevention, and the self-willed citizen]. Amsterdam: Van Gennep.

van Houdt, F. 2014. "Governing Citizens: The Government of Citizenship, Crime and Migration in the Netherlands." PhD diss., Erasmus University Rotterdam.

Verwey-Jonker, Hilda, ed. 1971. Allochtonen in Nederland: Beschouwingen over de Gerepatrieerden, Ambonezen, Surinamers, Antillianen, Buitenlandse Werknemers, Chinezen, Vluchtelingen, Buitenlandse Studenten in Onze Samenleving [Immigrants in the Netherlands: Reflections on the repatriates, Ambonese, Surinamese, Antilleans, foreign employees, Chinese, refugees, foreign students in our society]. The Hague: Ministerie van Cultuur, Recreatie en Maatschappelijk Werk.

Wodak, R. 2013. "Dis-citizenship and Migration. A Critical Discourse Analytical Perspective." Journal of Language, Identity and Education 12 (3): 173-178.

Wodak, R., R. de Cillia, M. Reisigl, and K. Liebhart. 2009. The Discursive Construction of National Identity. 2nd ed. Edinburgh: Edinburgh University Press.

WRR (Wetenschappelijke Raad voor het Regeringsbeleid). 2016. Migratie en classificatie: Naar een meervoudig migratie-idioom [Migration and classification: Toward a multiple migration idiom]. The Hague: WRR.

Yanow, D. 2000. Conducting Interpretive Policy Analysis. Newbury Park, CA: Sage.

Yanow, D. 2003. Constructing "Race" and "Ethnicity" in America: Category-Making in Public Policy and Administration. Armonk, NY: M. E. Sharpe.

Yanow, D., and M. van der Haar. 2013. "People Out of Place: Allochthony and Autochthony in Netherlands Identity Discourse: Metaphors and Categories in Action." Journal for International Relations and Development 16 (2): 227-261.

Yanow, D., M. van der Haar, and K. Völke, 2016. "Troubled Taxonomies and the Calculating State: Everyday Categorizing and 'Race-Ethnicity'—The Netherlands Case.” Journal of Race, Ethnicity, and Politics 1 (2): 187-226. 


\section{Notes}

${ }^{1}$ We generally follow the Dutch spelling allochtoon rather than the English dictionary allochthon, which reflects the original Greek. The Dutch plural is allochtonen, which we use, even though allochtoons might feel natural for English speakers, and the English plural is allochthones.

${ }^{2}$ Regarding these terms see Ramanathan (2013), Wodak (2013).

${ }^{3}$ All translations from non-English references are our own unless otherwise indicated.

${ }^{4}$ Lucassen and Lucassen (2015) show how the history of thinking and practice since the 1950s in the Netherlands is not well understood as a shift from a supposed left-wing pro-migration and multiculturalist orthodoxy to a right-wing counter-orthodoxy.

${ }^{5}$ We refer to paragraph $x$ in section $y$ as $[x . y]$, except forsections 2,4 , and 5 which each has a series of subsections, which we refer to as, for example, 2.1, each then with its own set of paragraphs (e.g., 2.2.1).

${ }^{6}$ Section 4 opens with four paragraphs on general principles, followed by subsections 4.1 and 4.2. We treat the opening paragraphs as subsection 4.0. The later subsections contain text boxes that list actions related to the previous paragraph (e.g., 4.1.2); we enumerate the bullet points in these boxes as, for example, 4.1.2:2.

${ }^{7}$ One highly specific policy commitment appears, as a striking exception: to counter the use of the drug qat, especially among Somali-Dutch [4.2.3].

8 "Problematization is the process in which actors analyse a situation, define it as a problem, elaborate it by attaching issues to it and by highlighting or even exaggerating the number of people or the costs and risks involved, and finally suggest a solution", say Schinkel and Schrover (2013: 1126), referring to Foucault (1984).

${ }^{9}$ More fully, we identify the following constructions that articulate government/cabinet mentality and actions:

- Views and beliefs. The government shares dissatisfaction [1.2], is aware of negative effects [1.3], and takes distance from $X$ [3.1]; the government acknowledges the existence of concerns over Islam [3.4]; the government assumes [3.1], considers [4.1.1], believes [5.2.6]; it expects $Y$ from citizens [1.4, 3.8, 4.1.2]; the government stands for freedom and responsibility [3.3], and attaches a great value to $Z$ [4.1.7]; and the government takes on the task of removing concerns [3.4].

- Actions. The government has set down $A$; it will submit $B$, focus on $C$, and examine, decide, make available, actively promote, enforce $D$; it combats $E$ [1.4]; the government strives for $F$ [3.8]; it will not grant $G$; it will have to make a stand to defend the national values of living together and confront those who violate them [5.2.4]. 
- Limits. The government should limit itself to primary duties [5.3.3]; it is not a substitute for civic involvement [3.7].

${ }^{10}$ As documented by van Dijk (1992), and discussed more recently by Schinkel and Schrover (2013), the right-wing press typically emphasizes the problems that immigrants are seen to create (in housing, schooling, unemployment, crime), whereas the more liberal press (also) focuses on the problems that immigrants have (as a result of poverty and discrimination).

${ }^{11}$ The details of the Western/non-Western demarcation were and remain remarkable; Japan and Indonesia were included as "Western" for this purpose, whereas Turkey was not.

${ }^{12}$ The language of Western versus non-Western disappears after the first fifth of the policy note, perhaps since Western allochtonen are considered as requiring little attention.

${ }^{13}$ In some usages in other writings, the term even extends to later generations.

${ }^{14}$ For example, within the lead clustering, non-Western allochtonen, special mention is made [in 2.1] of (1) some groups of prime policy concern: Turkish-Netherlanders; Moroccan-

Netherlanders; Surinamese-Netherlanders; Caribbean [Aruba or Antilles origin]; and (2) others from, "for example, China, Afghanistan, Iraq, Iran, Somalia" [2.1]. Within a crime-related clustering, several subgroups receive special mention, such as Antillean and Moroccan-Dutch high-risk youth [4.2.3]. Various other distinctive groupings arise, including entrepreneurs and highly educated "knowledge workers" [2.1], both non-Westerners and Westerners.

${ }^{15}$ For example, "Antillean and Moroccan high-risk youths" receive special mention [4.2.3]. They will, though, in the future not be dealt with separately but by the generic policy against "criminal youth groups and nuisance youth."

${ }^{16}$ For a parallel analysis from Denmark, see Kock and Villadsen (2017: 781): the Danish Prime Minister's 2016 New Year address praised Danish traditions of generosity but implicitly "portrays Denmark, not as a robust society, but as a vulnerable entity beset with danger from without" if it accepts asylum seekers on a large scale.

${ }^{17}$ For Berry (1997), four strategies of acculturation were possible, according to the degrees of (1) preserving own identity (I), and (2) openness to social contact with other cultures (R). Hence, the four are integration $(\mathrm{I}+, \mathrm{R}+)$, assimilation ( $\mathrm{I}-\mathrm{,} \mathrm{R}+)$, separation/segregation $(\mathrm{I}+, \mathrm{R}-)$, and marginalization (I-,R-). Integration preserves own inherited identity at the same time as seeking social participation and contact with other cultures; in assimilation, the minority group/individual chooses to give up the current identity, seek extensive contact with the dominant culture, and adopt it as "home." The typology does not cover a fifth type: "forced assimilation," in which a dominant culture imposes its will on the "others."

${ }^{18}$ In 2016, the scientific advisory council on government policy and the central bureau for statistics advised abandoning the terminology (WRR 2016). The statistics bureau now uses the terms 'persons with a Dutch background', 'persons with a Turkish background', and so on. 19 "Hoewel er onmiskenbaar sprake is van integratie en vele migranten met succes hun weg 
hebben weten te vinden in de economie, de cultuur, de politiek en het onderwijs, domineert de zorg over dat deel van de migranten dat er niet in slaagt in Nederland een zelfstandig bestaan op te bouwen." 